\title{
HIDDEN COST REDUCTIONS IN BANK MERGERS: ACCOUNTING FOR MORE PRODUCTIVE BANKS
}

\author{
Simon H. Kwan* \\ Federal Reserve Bank of San Francisco \\ James A. Wilcox \\ Office of the Comptroller of the Currency
}

\begin{abstract}
Over the past decade, the banking industry has undergone rapid consolidation; indeed, on average, for the past three years there were more than two bank mergers every business day. Before the 1990s, most bank mergers involved banks with less than $\$ 1$ billion in assets; more recently, even the very largest banks have merged with other banks and with nonbank financial firms.

Globalization, technological advances, and regulatory retreat are often cited as factors that have stimulated and allowed more banks to merge. Mergers may reduce costs if they enable banks to close redundant branches or consolidate back-office functions. Mergers may make banks more productive if they increase the range of products that banks can profitably offer. Mergers may also diversify further bank portfolios and thereby reduce the probability of insolvency. Increased diversification then may reduce banks' total costs by reducing desired capital-asset ratios. Increased diversification and size may also raise revenues if they increase banks' attractiveness to customers who will deal only with very safe institutions. Though banks' loan rates or noninterest revenues might rise or their deposit rates or capital requirements might fall as a result of mergers, we do not focus on those aspects of mergers here. Rather, we focus on the effects of merging on banks' noninterest expenses.
\end{abstract}

Simon H. Kwan is Senior Economist at the Federal Reserve Bank of San Francisco; James A. Wilcox is Chief Economist at the Office of the Comptroller of the Currency. The views expressed are those of the authors and do not necessarily represent the views of the Federal Reserve Bank of San Francisco, the Federal Reserve System, the Office of the Comptroller of the Currency, or the Department of the Treasury. 
One of the most striking aspects of the recent wave of bank mergers has been the split between bankers and economists about the practical importance of these advantages to merged banks on average. The managements of merging banks and industry analysts often project sizeable cost reductions, typically to be achieved by reducing labor and physical capital inputs. Economists in universities and in bank regulatory agencies have been hard pressed, however, to identify systematic, merger-related gains in bank productivity.

The lack of consensus even extends to the issue of which mergers are most likely to cut costs. Though there is some evidence from economists' estimates of banks' cost functions and post-merger performance studies that mergers of the smallest banks might reduce costs, little evidence has been found to support the claim that bank mega-mergers cut costs. One bank-merger advisor noted to us that the banking industry's ranking of the ability to reduce costs following bank mergers was the reverse of economists. His evaluation was that the industry regarded the overwhelming majority of mergers between large banks (those with at least $\$ 5$ billion in assets) as cutting costs, the mergers of middle-sized banks as having a mixed record on cost-cutting, and the overwhelming majority of mergers of banks with less than $\$ 300$ million of assets as having achieved few, if any, cost reductions.

Our view is that the data conventionally used to study whether mergers produce more efficient banks typically have underestimated a number of sizeable and long-lasting cost reductions that merged banks have achieved. A primary source of underestimates of cost reductions is found in the rules of accounting for mergers. The bank mergers of the 1990s have often triggered accounting adjustments that biased reported costs upward. The rules of purchase-method merger accounting often result in upward revaluations of the merged, or combined, banks' assets. Mergers in recent years have triggered increases in the accounting values of both physical and intangible bank assets. As a result, post-merger banks reported higher depreciation and amortization charges, even if they owned and operated the same buildings and equipment after the merger as they did before the merger. Below we identify the specific cost categories where this mergerdriven bias may be particularly large, long-lasting, and widespread. 


\section{Evidence on Post-Merger Cost Cutting}

\section{A. $\underline{\text { Statistical studies }}$}

Berger (1998) concurred with the results and views of many economists that bank mergers generally had little effect on noninterest costs. Boyd and Graham (1998) concluded that mergers of very small banks reduced costs. Banks of this size often had well under $\$ 100$ million in assets, which is likely to mean that the sample consisted primarily of banks that had fewer than three dozen employees.

It is often argued that the structure of technological advances has been such that larger operations could reduce average costs because of the large fixed-cost component in the "back-office" operations of banking, such as payment processing. Hancock, Humphrey, and Wilcox (1998) estimated that the Federal Reserve's electronic payments transfer system, Fedwire, exhibited increasing returns to scale. They reported that, indeed, the Fed reduced its average costs with higher volume, even after adjusting its costs for the ever-declining real costs of telecommunication and data-processing equipment. This suggests one specific part of bank operations where larger scale might reduce costs and thereby justify mergers.

Chamberlain (1998) reported that "other noninterest expenses" (ONIE) rose, while expenses attributed to premises and other physical assets and to labor declined following bank mergers. ONIE are the noninterest expenses other than those attributable to labor, occupancy, and equipment expenses. She concluded that on balance bank mergers did not lower banks costs. Based on our hypothesis about the upward revaluation of intangible assets, whose charges are included in ONIE, we would expect that mergers would raise reported ONIE, quite apart from any economic changes in ONIE. That same argument applies to the expenses for premises and other physical assets. In her sample, the reductions in the economic values of those expenses may have been overwhelmed by the accounting increases triggered by the mergers. 


\section{B. $\underline{\text { Case studies }}$}

Linder and Crane (1992) compared the changes in performance measures, such as operating income, of a group of banks that merged with those of a group that did not merge. They found little difference between the changes achieved by the two groups, which suggested that merging alone did not improve performance. Rhoades (1998) reported on case studies performed on nine recent bank mergers. These mergers were deliberately chosen as being most likely to reduce costs: The mergers involved large banks whose markets had substantial geographic overlap. He concluded that only four of the mergers cut costs relative to those of non-merging peer banks, even though all of the mergers produced cost cuts in line with the banks' projections. The largest cost reductions were achieved by reducing the numbers of employees and by reducing computing expenses. Often about half of the cost cuts were attributed to reduced labor costs. Though more efficient banks tended to take over less efficient banks in Rhoades's sample, efficiency gains were not well predicted by the absolute or relative efficiency of the dominant partner, nor did other performance measures or size help systematically predict which mergers would most cut costs.

\section{Industry Analysis}

Bender and Marks (1996) disputed whether bank mergers were likely to raise profits by reducing costs. They analyzed mergers of very large banks (Bank of America and Security Pacific, Chemical and Manufacturers Hanover, etc.). They reasoned that though larger banks sometimes operated more cost efficiently, reduced operational costs rarely translated into higher profits because of increased loan losses and reduced ability to serve the profitable small-business segment of the commercial loan market. Bender and Marks (1996) also argued that technological advances may well have reduced the scale required to minimize average technology costs: Outsourcing possibilities and the advent of off-the-shelf hardware and software made it feasible for smaller banks to deliver technology-related services about as cheaply as larger banks did.

According to an article in the June 20, 1998 issue of the Economist, Andersen Consulting calculated that smaller banks have been consistently 
more cost-efficient in recent years than larger banks. Andersen calculated that, since 1995, banks with less than $\$ 10$ billion of assets had expenses (including loan loss provisions and restructuring charges) per individual or small business customer that were about 20 percent lower than those at larger banks. Profits per customer were also lower at larger banks.

\section{Summing Up}

Pilloff and Santomero (1998) surveyed both the statistical and case study literature on bank mergers. Based on their reading of the enormous empirical literature on bank costs, they concluded that on average the market valued the combined firm no higher than it did the separate components. Had merging cut costs, higher total market value would have been anticipated. Furthermore, on average, no empirical studies have reported performance gains after merging. Thus, the academic literature provides little evidence that banks reduced costs by merging. Analysis by industry analysts also suggests skepticism about the cost-reducing benefits of mergers.

\section{Data}

Our merger sample is obtained from the merger file at the Federal Reserve Bank of Chicago, which contains 8032 bank mergers between 1985 and 1997. We select bank mergers from the merger file using the following sampling criteria: (i) both of the merged banks must be healthy institutions at the time of the merger; (ii) both merged banks did not engage in another merger two years before or after the merger date; (iii) both institutions must be in operation for at least two years prior to the merger and must have total assets greater than $\$ 10$ million during the merger quarter; (iv) the accounting method (pooling of interest versus purchase accounting) for the merger transaction must be known and can be verified from the Wharton Research Data Service; and (v) the merger must occur before 1996.

The first criterion eliminates all failed-bank mergers and governmentassisted bank mergers. The second filter allows us to compare the twoyear pre- and post-merger performance without the contamination of another merger. The third criterion ensures the availability of banking data 
for at least two years before the merger date, and eliminates the smallest institutions from the sample. The accounting method criterion is necessary for the adjustment of reported cost data that is the key to this study. Finally, we exclude the most recent mergers that do not have at least three years of reported data after the merger date. ${ }^{1}$ These sampling criteria yield a sample of 1154 bank mergers. Out of this sample, banks in 20 mergers reported expenses that are either negative or unrealistically large. ${ }^{2}$ Eliminating these outliers produces a final sample of 1134 bank mergers.

The benchmark for measuring the performance of merged banks is a control sample of banks that did not engage in any mergers between 1985 and 1997. Like the merger sample, we also eliminate from the control sample for each quarter banks with total assets less than $\$ 10$ million, banks that are less than two years old, and banks that report negative or unrealistically large expenses. The number of banks in the control sample varies during the sampling period. For example, we have a total of 5475 banks in the control group in 1987 Q1. In each quarter, all banks in the control sample are grouped into four size categories: (i) small banks with total assets between $\$ 10$ million and $\$ 100$ million, (ii) medium banks with total assets between $\$ 100$ million and $\$ 1$ billion, (iii) large banks with total assets between $\$ 1$ billion and $\$ 10$ billion, and (iv) mega banks with total assets in excess of $\$ 10$ billion.

For each bank in the merger sample or the control sample, we obtain financial statements that are reported quarterly to the FDIC in the Call Report. From the income statement, we obtain the following noninterest expense data: salaries and costs of employee benefits, expenses on premises and fixed assets, and other noninterest expenses. ${ }^{3}$ Within the class of other noninterest expense, we also obtain the information on the amortization expense for intangible assets. From the balance sheet, we obtain the dollar value of the following quarter-end data: premises and fixed assets, intangible assets, and total assets.

\section{Methodology}

To measure the post-merger change in bank operating performance, we compare the post-merger performance of the merged bank relative to its 
control group of similar sized banks with the pre-merger performance of the merged banks relative to the peer group. Thus, we define Change in Relative Operating Costs (CROC) for the ith bank merger as:

$$
\left[\overline{\mathrm{X}}_{\mathrm{Ai}}-\overline{\mathrm{X}}_{\mathrm{A}}^{\mathrm{PEER}}\right]-\left[\overline{\mathrm{X}}_{\mathrm{Bi}}-\overline{\mathrm{X}}_{\mathrm{B}}^{\mathrm{PEER}}\right]
$$

where subscript A stands for after-merger and subscript B stands for before-merger. The four performance variables to be analyzed are: (i) ratio of total noninterest expenses to total assets (NIE), (ii) ratio of labor expenses to total assets (LAB), (iii) ratio of premises expenses to total assets (PREM), and (iv) ratio of other noninterest expenses to total assets (ONIE).

We compare each merger with one of the four size-based peer groups according to the combined quarter-end total assets of the acquirer and the target in the quarter immediately before the merger date, based on the same size cutoffs for the control group. The absolute performances of each peer group $\left(\mathrm{X}^{\mathrm{PEER}}\right)$ are the averages across all banks in the group of the eightquarter mean of the performance variable before and after the merger. For the merged bank and its predecessor banks, the absolute performance measures $\left(X_{i}\right)$ are the eight-quarter mean of the performance variable before and after the merger quarter. ${ }^{4}$ Subtracting the absolute performance of the peer group from that of the merged bank produces the relative performance of the merged bank before and after the merger. Subtracting the relative performance of the merged bank before the merger from its relative performance after the merger yields the Change in Relative Operating Costs. A negative CROC indicates cost savings were achieved after the merger.

\section{Accounting Issues}

Currently, according to Generally Accepted Accounting Principles (GAAP), there are two methods to account for business combinations: purchase accounting versus pooling-of-interests. In purchase accounting, all the assets of the target bank have to be marked to market before they are combined with the acquiring bank's assets, including the target bank's premises and equipment. The difference between the purchase price and 
the revised book value of target bank's equity, after marking all target bank's assets to market, will be recorded as goodwill, an intangible asset, in the surviving bank's book. All intangible assets must be amortized and expensed per GAAP. Hence, in purchase accounting mergers, both the stock of bank premises and the stock of intangible assets for the surviving bank would likely be higher than those of the combined total of the acquirer and target before the merger due to purchase accounting alone.

If the recorded bank premises and intangible assets are marked up due to the use of purchase accounting, the surviving bank's depreciation charge and amortization expense will rise instantly, even if the surviving bank changes nothing after the merger.

In pooling-of-interests, the target bank's assets, liabilities, and owner's equities are combined with those of the acquiring bank at book value as though the two companies had always been commonly owned. Thus, the reported assets of the merged bank would be equal to the sum of the reported assets of the two merging banks, absent any real changes in bank assets after the merger. Hence, unlike purchase accounting, pooling-ofinterests would not trigger additional depreciation expenses or goodwill charges. However, the merging banks must satisfy all the conditions for pooling, including certain pre-merger attributes such as comparable sizes, and post-merger activities limiting assets sales or stock repurchase; otherwise, the purchase accounting method must be used.

Figure 1 shows that in our merger sample, about one-third of the mergers used purchase accounting method to account for the merger transaction, and the percentage of purchase accounting mergers also was rising during our sampling period. Figure 2 shows that the average ratio of market value to book value equity for banking companies was also rising. As a result, the purchase accounting effect on reported expenses is likely to be larger during the latter part of the sampling period than during the earlier part.

To obtain a more accurate measure of the change in genuine operating performance of a merged bank that uses the purchase accounting method, we adjust the merged bank's reported premises expenses and other noninterest expenses by the amount that is attributable to the purchase accounting revaluations. Specifically, denote the quarter when the merger is consummated as quarter 0 and the quarters immediately before and after as quarters -1 and +1 , respectively. We first compare the reported fixed 
premises of the merged bank in quarter 0 to the combined total fixed premises of the two constituent banks in quarter $-1 .^{5}$ If the reported fixed premises go up after the merger, we assume that this is due to the revaluation of the target bank's premises. We then attribute the difference between the reported quarter +1 and quarter -1 premises expenses as the incremental premises expense attributable to purchase accounting, denoted as XP. XP is then subtracted from the reported premises expense for all post-merger quarters in calculating the adjusted premises expenses (PREMXP). We perform the same adjustment on reported intangible assets between quarter 0 and quarter -1 . Assuming the difference between quarter +1 and quarter -1 amortization expenses as the incremental amortization expense triggered by purchase accounting, denoted as XG, the adjusted noninterest expense (ONIEXG) is calculated by subtracting XG from ONIE for all post-merger quarters. Finally, we adjust total noninterest expense by subtracting both XP and XG from NIE, denoted as NIEXPXG.

\section{Findings}

Table 1 presents the average change in relative operating costs for 1134 bank mergers between 1987 and 1995. In the first panel, the average change in total noninterest expense of merged banks was -0.003 . Although the negative sign indicates that on average, banks cut total noninterest expenses after the merger, the cut was not statistically significantly different from zero. Of the three operating cost components, labor costs registered the largest drop after the merger, falling an average annual amount of 0.02 percent of total assets. Unadjusted premises expenses, however, on average went up by 0.009 percent of total assets after the merger, and the increase is significant at the 5 percent level. While unadjusted other noninterest expense also rose after mergers, the increase is not statistically significant.

As shown in the middle panel of Table 1, purchase accounting triggered significant incremental premises expenses (XP) and incremental intangible expenses (XG). Additional premises expenses, XP, averaged 0.016 percent of total assets, and additional intangible expenses, $\mathrm{XG}$, averaged 0.022 percent of total assets. In the bottom panel, adjusting premises expenses by XP yields a significantly negative change in PREMXP, indicating that 
merged banks on average did cut occupancy costs; occupancy expenses declined by 0.008 percent of total assets after merging. After adjusting for the incremental amortization expense, changes in ONIEXG becomes negative, but it is not significant. Regarding total noninterest expense, the adjusted NIE, NIEXPXG, on average fell by a significant 0.042 percent of total assets after the merger. This suggests that bank mergers do result in operating cost savings. For a merged bank that earns say, 1 percent return on assets (ROA), the average cost savings reported in Table 1 translate into a 4 percent increase in ROA.

In Table 2, we repeat the analysis after dividing the merger sample into three time periods: $1987-89,1990-92$, and 1993-95. We find that even without the purchase accounting adjustments, total noninterest expense fell by 0.049 percent of total assets after the merger in the 1993-95 subperiod, and the cost saving is statistically significant. Of the three operating cost components, labor cost showed the largest cut in the 1993-95 subperiod, whereas unadjusted premises expense showed a significant rise after the merger in this time period.

The adjustment for premises expense is significantly positive in all three subperiods. The adjustment for amortization expense rose over time, and is significantly positive during the two most recent subperiods. This reflects the fact that purchase premia over the book values of target banks were rising over time, as the market value of banking companies were rising in general.

Adjusting the premises expense by the XP turns the positive changes in PREM to negative changes in PREMXP after the merger, but none of the changes in PREMXP in the three subperiods are significant. On the other hand, changes in adjusted ONIE, ONIEXG, is found to be significantly negative in the last two subperiods, indicating that merger related cuts in other noninterest expense on average exceed labor cost savings. On net, mergers in 1993-95 shaved adjusted total noninterest expense, NIEXPXG, by a statistically significant 0.1 percent of total assets, which is equivalent to a 10 percent boost in a 100 basis points ROA. Change in NIEXPXG is insignificant for the two earlier time periods.

Table 2 clearly suggests that recent bank mergers seem to cut operating costs more than earlier bank mergers. To test this hypothesis formally, we compare the cost cuts for mergers in 1993-95 to those that occurred in 1987-92. In Table 3, we regress each performance measure against a 
dummy variable for 1993-95 mergers and an intercept term. The coefficient on the dummy is found to be significantly negative for the NIEXPXG regression, confirming that the cost savings for mergers in 1993-95 were significantly larger than those in earlier time periods. The 1993-95 mergers dummy is also significantly negative for the unadjusted NIE regression, as well as for the ONIEXG regression.

Finally, to test whether mergers involving large banks cut costs more than mergers among smaller banks, we regress each performance measure against a dummy variable for large merger and an intercept term separately for the three time periods. The dummy variable for large merger equals one if the total assets of the merged bank at the time of the merger exceeds $\$ 1$ billion, and equals zero otherwise. Table 4 shows that on balance, cost savings in large bank mergers did not differ significantly from smaller bank mergers. In the NIEXPXG regressions, while the coefficient of the large merger dummy is positive in the two earlier subperiods, it becomes negative in 1993-95, providing some weak evidence that the operating performance of large mergers, relative to their smaller counterparts, seemed to be improving over time.

\section{Conclusions}

In this study, we revisit an important question in banking: Do bank mergers lead to operating cost savings? While the majority of past research did not find significant cost reduction after banks merged, bank managers and banking consultants cite improving operating cost efficiency as a primary motivation for bank mergers. This is probably one of the starkest discrepancies between banking researchers and practitioners.

In this study, we recognize an important measurement issue in using reported financial data to compare pre- and post-merger operating performance. In mergers where the purchase accounting method is used to account for the business combination, all the assets of the target institution have to be marked to market before being combined with the acquirer's book assets, and the difference between the purchase price and the revised book value of target bank's equity is recorded as goodwill in the surviving bank's book. These additional assets must be expensed according to the amortization schedule under GAAP. 
The purchase accounting method therefore can trigger additional occupancy expense and amortization expense by the surviving bank that have nothing to do with actual costs. Hence, to measure performance change before and after the merger more accurately, this study adjusts the reported data to eliminate the pure accounting effects on reported costs. In addition, we also include more recent data in our analysis so that we cover a period when the banking industry is financially much stronger and the pace of banking consolidation is rapid.

We find evidence that bank mergers reduced operating costs. Both labor cost and occupancy expense are found to decline significantly after the merger. The cost reductions during the full sampling period are evident only after we remove the pure accounting effects on reported expense data, confirming that merger accounting can hide a significant portion of cost cuts. Nonetheless, our subperiod analysis suggests that only more recent bank mergers were able to achieve significant cost cuts, with the accounting bias hiding one-half of the cost reduction. Earlier mergers did not seem to produce cost savings, despite the removal of the accounting bias. We also find that the size of the merging institutions does not have significant effects on the amount of cost savings.

\section{$\underline{\text { Endnotes }}$}

1. For robustness, we also conduct three-year pre- and post-merger performance comparisons. They produce qualitatively similar results.

2. We consider annualized labor costs in excess of 5 percent of total assets, annualized premises expenses in excess of 5 percent of total assets, or annualized other non-interest expenses in excess of 10 percent of total assets to be outliers.

3. Other noninterest expense includes 34 categories of expense items. For example, it includes fees paid to directors for attending board meetings, Federal Deposit Insurance assessments, legal fees, amortization expense of intangible assets, costs of data processing, and advertising and promotional expenses. 
4. Note that data for the merger quarter are omitted from the analysis. In the cases where the purchase accounting method was used for the merger transaction, the merged bank reported the expenses equal to the acquirer's full quarter of expenses plus the expenses incurred by the target from the merger consummation date through the end of the quarter. This makes the reported quarterly expenses of the merged bank for the merger quarter inconsistent with the pre- and post-merger quarterly expenses.

5. The balance sheet variables for the merged bank reported for the merger quarter are stock variables as of the end of the quarter and are free of the "flow" problem noted in endnote 4.

\section{$\underline{\text { References }}$}

Bender, Arthur K., and James M. Marks. "Bank Merger Mythology: Why Bank Mergers Do Not Benefit Acquiring Shareholders," Sutro \& Co. Special Report, March 25, 1996.

Berger, Allen N. "The Efficiency Effects of Bank Mergers and Acquisition: A Preliminary Look at the 1990s Data." In Bank Mergers \& Acquisitions, edited by Yakov Amihud and Geoffrey Miller, Kluwer Academic Publishers, 1998.

Boyd, John H., and Stanley L. Graham. "Consolidation in U.S. Banking: Implications for Efficiency and Risk." In Bank Mergers \& Acquisitions, edited by Yakov Amihud and Geoffrey Miller, Kluwer Academic Publishers, 1998.

Chamberlain, Sandra L. "The Effect of Bank Ownership Changes on Subsidiary-Level Earnings." In Bank Mergers \& Acquisitions, edited by Yakov Amihud and Geoffrey Miller, Kluwer Academic Publishers, 1998.

Hancock, Diana, David B. Humphrey, and James A. Wilcox. "Cost Reductions in Electronic Payments: The Roles of Consolidation, 
Economies of Scale, and Technical Change," Journal of Banking and Finance, Forthcoming 1998.

Linder, Jane C., and Crane, Dwight B. "Bank Mergers: Integration and Profitability," Journal of Financial Services Research 7 (1992), 35-55.

Pilloff, Steven J., and Anthony M. Santomero. "The Value Effects of Bank Mergers and Acquisitions." In Bank Mergers \& Acquisitions, edited by Yakov Amihud and Geoffrey Miller, Kluwer Academic Publishers, 1998.

Rhoades, Stephen A. "The Efficiency Effects of Bank Mergers: An Overview of Case Studies of Nine Mergers," Journal of Banking \& Finance 22 (1998), 273-291. 
TABLE 1

\section{Do Mergers Cut Costs?}

Change in 8-quarter mean relative operating costs

1134 mergers between 1987 and 1995

(percent of total assets)

\begin{tabular}{lc}
\hline NIE & -0.003 \\
LAB & $-0.020^{*}$ \\
PREM & $0.009^{*}$ \\
ONIE & 0.008 \\
& \\
Adjustments: & \\
XP & $0.016^{*}$ \\
XG & $0.022^{*}$ \\
& \\
Adjusted Expenses: & \\
PREMXP & $-0.008^{*}$ \\
ONIEXG & -0.014 \\
NIEXPXG & $-0.042^{*}$ \\
\hline
\end{tabular}

*: Significant at the 5\% level. 
TABLE 2

Do Recent Mergers Cut Costs More?

Change in 8-quarter mean relative operating cost

1134 mergers between 1987 and 1995

(percent of total assets)

\begin{tabular}{llll}
\hline & $\underline{1987-89}$ & $\underline{1990-92}$ & $\underline{1993-95}$ \\
NIE & 0.045 & -0.005 & $-0.049^{*}$ \\
LAB & -0.014 & -0.009 & $-0.037^{*}$ \\
PREM & 0.006 & 0.009 & $0.011^{*}$ \\
ONIE & $0.053^{*}$ & -0.006 & -0.023
\end{tabular}

Adjustments:

$\begin{array}{llll}\text { XP } & 0.015^{*} & 0.018^{*} & 0.016^{*} \\ \mathrm{XG} & 0.009 & 0.022^{*} & 0.036^{*}\end{array}$

Adjusted Expenses:

\begin{tabular}{clll} 
PREMXP & -0.01 & -0.009 & -0.005 \\
ONIEXG & $0.045^{*}$ & $-0.027^{*}$ & $-0.058^{*}$ \\
NIEXPXG & 0.021 & -0.045 & $-0.100^{*}$ \\
\hline
\end{tabular}

*: Significant at the 5\% level. 
TABLE 3

Was 1993-95 Significantly Different?

1134 mergers between 1987 and 1995

(percent of total assets)

\begin{tabular}{|c|c|c|}
\hline & $\begin{array}{l}\text { Dummy Variable } \\
\text { for 1993-95 } \\
\end{array}$ & $\underline{\text { t-statistic }}$ \\
\hline NIE & $-0.068 *$ & -2.37 \\
\hline LAB & -0.026 & -1.76 \\
\hline PREM & 0.004 & -0.54 \\
\hline ONIE & $-0.046^{*}$ & -2.26 \\
\hline \multicolumn{3}{|c|}{ Adjustments: } \\
\hline XP & -0.001 & -0.27 \\
\hline $\mathrm{XG}$ & $0.021 *$ & -3.41 \\
\hline \multicolumn{3}{|c|}{ Adjusted Expenses: } \\
\hline PREMXP & 0.004 & -0.63 \\
\hline ONIEXG & $-0.066^{*}$ & -3.27 \\
\hline NIEXPXG & $-0.087 *$ & -3.05 \\
\hline
\end{tabular}

*: Significant at the 5\% level. 
TABLE 4

Do Large Mergers Cut Costs More?

Coefficients on dummy variable for large mergers

1134 mergers between 1987 and 1995

(percent of total assets)

\begin{tabular}{llll}
\hline & $\underline{1987-89}$ & $\underline{1990-92}$ & $\underline{1993-95}$ \\
NIE & 0.02 & 0.094 & -0.073 \\
LAB & 0.031 & -0.032 & -0.084 \\
PREM & 0.035 & $-0.052^{*}$ & -0.003 \\
ONIE & -0.047 & $0.178^{*}$ & 0.014
\end{tabular}

Adjustments:

$\begin{array}{llll}\text { XP } & -0.022^{*} & -0.013 & -0.015 \\ \mathrm{XG} & 0.003 & 0.002 & -0.003\end{array}$

Adjusted Expenses:

\begin{tabular}{clll} 
PREMXP & $0.058^{*}$ & $-0.039 *$ & 0.012 \\
ONIEXG & -0.05 & $0.175^{*}$ & 0.012 \\
NIEXPXG & 0.039 & 0.104 & -0.06 \\
\hline
\end{tabular}

*: Significant at the $5 \%$ level. 
Figure 1: Percentage of Bank Mergers Using Purchase Accounting

number

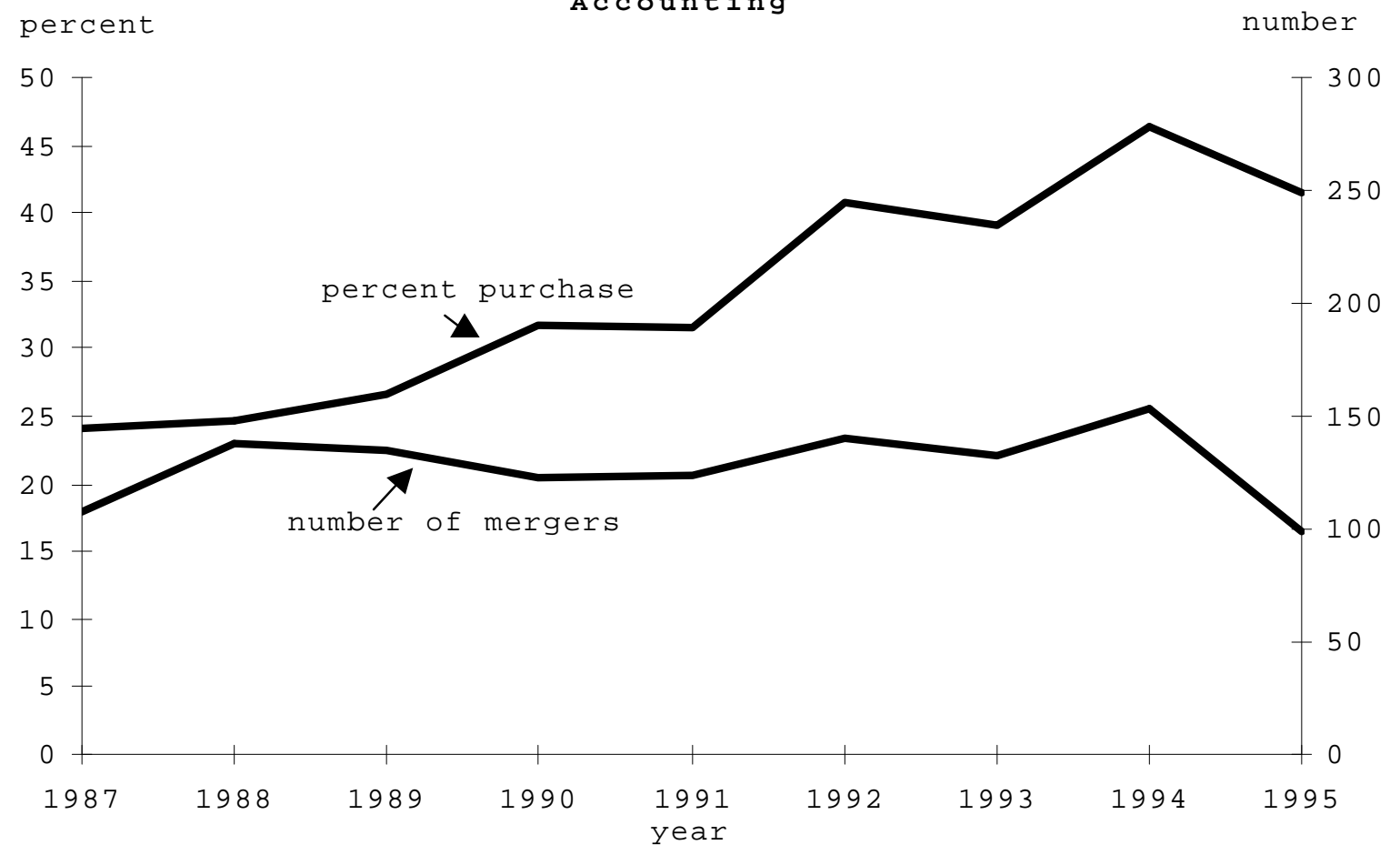


Figure 2: Average Price-to-Book Ratio

Price-to-Book

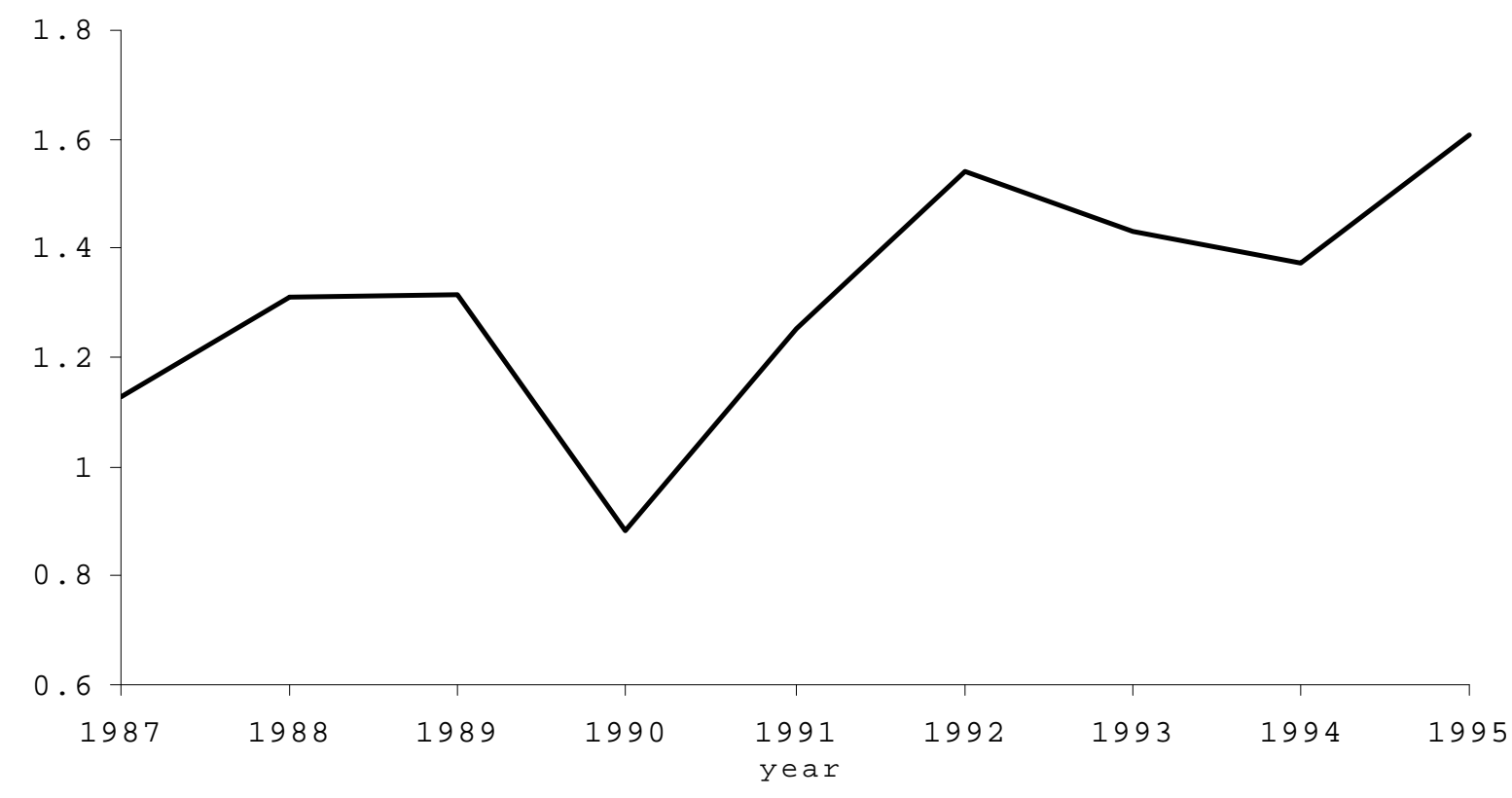

